\title{
Challenges Faced by Pre-service Science Teachers during the Teaching and Learning Process in Turkey
}

\author{
Zeynep Başkan Takaoğlu ${ }^{1}$ \\ ${ }^{1}$ School of Health, Gümüşhane University, Turkey \\ Correspondence: Zeynep Başkan Takaoğlu, School of Health, Gümüşhane University, Turkey.
}

Received: December 6, 2016

Accepted: December 18, 2016

Online Published: January 6, 2017

doi:10.11114/jets.v5i2.2132

URL: http://dx.doi.org/10.11114/jets.v5i2.2132

\begin{abstract}
Pre-service teachers' first experiences and ideas prior to application affect their teaching activities. For this reason, it is aimed to determine transferring the experiences and ideas of prospective science teachers before lesson activities and its development with lesson activities. The study was carried out with 29 third year prospective teachers who attended the course named Laboratory Application II and undergraduate students at the Department of Science Education at Karadeniz Technical University during 2012-2013 spring semesters. The study was conducted by case study design. Thirty-minute lesson activities were carried out by them. Reflective writings constituted by candidates, lesson observations and plans were used as data collecting tools. They were examined through inductive thematic analyze. When compared before and during lesson activities process, it was determined that pre-service teachers' perception, ideas or application had changed at some concepts. This case might be a proof of development of pre service teachers' professional skills doing practice.
\end{abstract}

Keywords: lesson activities, pre- service science teacher, teacher education, teaching experience

\section{Introduction}

Education and training activities have an important role in the development of countries (Aydın, 2003). On the basis of these activities, teachers are the key players (Becit, Kurt \& Kabakçı, 2009). For this reason, it is important that quality teachers be prepared using quality education and instructional activities. Before the service, duty of educating quality teachers belongs to the teacher training program (Işık, Çiltaş \& Baş, 2010). In this context, teacher training programs should constantly be improved in line with the needs of today's world (Alev \& Yiğit, 2006). A comprehensive innovation has been done in the field of teacher education in cooperation with Higher Education Council and World Bank in Turkey in 1999 and as a result, new courses have been added to the field of teacher education programs related to education by giving more importance to subject matter education beside pedagogical knowledge in teacher education programs (Yüksek Öğretim Kurulu, YÖK, 2007). In this way, it has been aimed to modernize teacher education and develop prospective teachers with appropriate teaching methods and techniques.

Teacher training institutions usually do not mention about complexity and content of the school and cannot give a lot of importance to teaching activities (Haney \& McArthur, 2002; Hart, 2002). Therefore, experiences and attitudes of prospective teachers before the teaching application are very important (Wilkins \& Brand, 2004). The cases experienced by pre- service teachers before the application, reveal their lesson presentation and cases that attach importance. In addition, it is expressed in most studies that prospective teachers' prior knowledge or attitudes before teaching experiences influence their lesson activities (Desouza, Boone, \& Yilmaz, 2004; Haney \& McArthur, 2002; Prosser \& Trigwell, 1997; Ogan- Bekiroğlu \& Akkoç, 2009). But it should not be forgotten that the beliefs of prospective teachers can be changed by effective teacher training (Raths, 2001; Ogan- Bekiroğlu \& Akkoç, 2009). In this context, it is known that some attitudes can be changed while others can remain stable during teacher training education $(\mathrm{Ng}$, Nicholas, \& Wiliams, 2010). Teacher training institutions have the duty to be aware of the concerns of prospective teachers and the problems they may face and help them overcome these problems before going to the schools which are the actual environment of application. The aim is to highlight individuals' awareness education, determine the missing points in their development and contribute to their improvement accordingly (Hart, 2002; Wilkins \& Brand, 2004). As a result, prospective teachers will gain self-confidence against difficulties during course presentation (Yilmaz- Tüzün; 2008) and their teaching skills will improve (Tosun, 2000) Otherwise, imperfect or incorrect ideas produced by prospective 
teachers become a pattern and this cause to take the form of belief (Ogan- Bekiroğlu \& Akkoç, 2009).

It is usual not to mention the complexity and content of the school and give a lot of importance to teaching activities in teacher training institutions (Cole \& Knowledges, 1993). Prospective teachers begin university education with different conceptual knowledge, and most universities cannot help student teachers with subject matter knowledge and pedagogical knowledge (Adams \& Krockover, 1997; Sperandeo- Mineo, Fazio \& Tarantino, 2005). There is a basic connection between knowledge and teaching and they can be assessed together instead of discussing them separately. In this context, Shulman (1986) identified pedagogical content knowledge which is the combination of subject matter knowledge and pedagogical knowledge as well as defining these two areas. Consequently, Shulman (1987) emphasized on the importance of applications like demonstrations, analogies, models, varied classroom activities, metaphors and examples to transform subject matter knowledge understandable for students. A teacher to work in the education area needs to have the basic information to be able to transfer subject matter knowledge as well as having subject matter knowledge itself. This case is known as learning to teach (Shulman, 1986; Shulman, 1987). It is necessary for teachers to have the skills of transferring required subject matter knowledge to the learners. A teacher has to present an effective lesson on the subject, needs to have, good subject matter knowledge, the knowledge of instructional strategies and activities, the knowledge of students' learning difficulties, the knowledge of curriculum, and the knowledge of assessment (Kaya, 2009; Shulman, 1987). It is known that this deficiency can be met by the teacher education program to be applied to prospective teachers.

Another skill expected from the teachers is to plan and implement teaching activities in pre-service (Driel, John \& Verloop, 2002; Roskos \& Walker, 1994). For this reason, it is suggested to let prospective teachers perform short-term lesson activities in universities (Driel, et al., 2002). On the other hand, studies are not sufficient at lessons related with teacher training program for reflecting this case. Development of teaching information of prospective teachers and examining the lessons they have prepared is enabled through the lessons to be conducted on the field, and this case contributes to the development of prospective teachers. In this sense, answers have been sought for two main research questions:

1. How did pre- service teachers put the experiences and ideas into practice before lesson activities?

2. What were pre- service teachers' development on the experiences and ideas with lesson activities?

\section{Method}

\subsection{Research Design}

The study is based on qualitative research approach. Merriam (2009); expresses that qualitative research as the source of research which provides very big opportunities to researchers to reveal the differences in individuals' lives. Furthermore, qualitative researches are used when specific groups are focused (Yin, 2011).

Case studies are often preferred in the qualitative research process. It offers researchers to focus on a specific case or topic (Çepni, 2007). One of the case study types is single case design. This design helps to investigate a case deeply and there is one case and events supporting the case (Yin, 2009). Therefore, this study is appropriate to the nature of single case design.

\subsection{Research Process}

Firstly one gain in elementary education science teaching program about "electricity in our lives" unit was selected and given to prospective teachers. It was asked to design a student orientated teaching plan which is appropriate for this gain and then report it. The existence of the same units in both classes derived from the spiral principle in the elementary school program. The same units existing in different classes are a continuation of each other.

In the next step of the study, nearly 30-minute lesson activities were asked from prospective teachers. Applications were carried out in the lab and U-shape class organization. Within this period, although it is noted that prospective teachers can use whichever student centered approach they want, all of the candidates preferred $5 \mathrm{E}$ model of the constructive approach. The reason why this model was preferred can be due to the preparation of science course books based on the same approach. During the presentation of candidates, unstructured observations were conducted by researchers and self-evaluation of each candidate was asked at the end of the lesson activity. Also, some suggestions were made with the help of class discussion and observations. In the last step of study, reflective writings reporting before and process lesson activity experiences were asked from the candidates.

\subsection{Participants}

The universe of the study consists 3rd grade pre- service science teachers studying in Karadeniz Technical University, Fatih Faculty of Education, Science Teaching Program in the spring semester of the 2012- 2013 academic years. Because of selecting these pre- service science teachers, short term courses are taught by them in the 4th grade for two 
semesters in the secondary schools. This study includes a preliminary preparation for 4th class school practices lessons. Third pre-service teachers selected hence this reason. Participants consisted of; prospective teachers selected randomly from a class in which everyone takes the course of Laboratory Applications II and prospective teachers determined by randomly selecting a class and separating it into two groups. Determined class list was divided into two halves and one was selected randomly. Applications were conducted with 29 candidates including 21 women, and 8 men. Participants' age ranged change between 20 and 26. Names of prospective teachers were encoded as S1, S2, .. for privacy.

\subsection{Data Collection Tools}

Although precise data collection tools are not put forward for classroom experiences in teaching activities, data collection tools like classroom observations and diaries are usually recommended (An, Kulm, \& Wu, 2004; Kiliç, 2009). Hence, the data was collected by using reflective writings, observations and lesson plans.

Reflective writing allows pre- service teachers to evaluate themselves and the ability to look cases from different perspectives (Cengiz \& Karataş, 2014). Reflective writings were asked from prospective teachers for the experience before and during of the lesson activities, and their lesson plans. Pre- service teachers were asked about their experiences they had before and in the process of the lesson, about their feelings about these experiences, to explain the reasons of their behavior before and during lesson activities, and to evaluate themselves from positive and negative aspects.

The data was collected by researchers to determine the behavior of the pre- service teachers at observations. During the data collection process researcher if required got in contact with the pre- service teachers and tried to find out the cause of behavior with the help of asking questions about the research subjects. Participant observations were conducted for the aim of determining experiences of lesson activities by the researcher. It was included in unstructured observations because the researcher converted observations to writing format in the lesson activities process and did not create any observation schedule before the classroom applications. The researcher wrote the data at registration of observations while watching the lesson. Behavior and its causes of per- service science teachers were translated into text in lesson presentations. Since any observation charts had not been used, observations was unstructured in nature.

Lesson plans and supplement materials (transparent, work sheets, videos, pictures etc.) formed in the application process by prospective teachers were examined document review. For this goal, the lesson plans prepared by prospective teachers were gathered by the researcher before lesson activities started. Despite demanding student centered any approach proper lesson plans from pre- service science teachers, all of them preferred constructivist approach. This is because it may be preferred to constructivist approach in science textbooks.

\subsection{Data Analysis}

Thematic analysis method was used for examining the data obtained from reflective writings, observations and lesson plans. The reason for preferring thematic analysis method is that it examines the data systematically and this allows the use of advanced analyses (Altunışık, Coşkun, Bayraktaroğlu \& Yıldırım, 2005). For this reason, reflective writings were read first, and first level codes had been formed from the data related with the problem status in the study. In this context, the second level codes had been produced by grouping first level codes between each other. Second level codes helped the formation of themes (Miles \& Huberman, 1994). With the help of obtained codes, themes were constituted for the experiences of prospective teachers before and during application.

Similar reflective writings analyses method, firstly unconnected data was removed from observations in the analyses of obtained data. Then, first and second level codes were constituted. These codes were placed in themes constituted in the process of prospective teachers' experiments in reflective writings. New themes were formed at required points in the observations and determinated codes were grouped under these themes like classroom management, presentation types, time and etc.

In the next step of the analysis process, lesson plans prepared by prospective teachers were examined. Identified codes in the examined lesson plans were grouped under the themes constituted in the process of prospective teachers' experiments, and new themes were formed at necessary points.

At the end of the analysis process, the study was converted to a text by using the data obtained, themes and codes. Direct quotations from examined data were used at necessary points in the study.

\section{Results}

Data obtained from prospective teachers were grouped under two main parts in presentation of findings. Firstly, reflective writings of candidates were examined and experiences before lesson activities were explained. Then, during lesson experiences were presented by making use of reflective writings, observations and lesson plans. 


\subsection{Experiences before Lesson Activities}

When prospective teachers' experiences before lesson activities were examined, it was determined that they expressed ideas about time, experiment materials, emotions, technology and instructional technologies, lesson and supplementary books, friend interaction, gains, lesson plans and classroom observations (Appendix A).

\subsubsection{Time}

Prospective teachers encountered some challenges about time because of studying their lesson activities the last day or studying more effectively at that time, reviewing again at the last moment, and being overloaded with too much homework. On the other hand, some candidates expressed that they had prepared their lesson plans and materials days ago before they taught the lesson.

"My teaching activity was on the last week of the semester. Yet, it wasn't until last evening when I completed my study. I had made the sketch on my mind on how I would teach the lesson thoroughly. But there was nothing clear yet..." (S24)

\subsubsection{Experiment Materials}

Pre- service have expressed that they faced difficulties about not being able to find appropriate materials for the experiments, realizing that the materials were broken before the activities, and coming to school with incomplete or incorrect materials. Some candidates have stated that they have not had any material shortage.

"I've had difficulty in finding materials. I have made my experiment successfully with a comb in my dorm. But my activity failed in the classroom because I used a plastic pen during my presentation." (S6)

\subsubsection{Course Book and Supplementary Books}

While some candidates were unable to reach the course book, some of them stated that they had not found the additional resources to help them for teaching the lesson. In addition, some candidates expressed that course books had not made adequate guidance to them.

"I hoped I would design various lesson activities if I benefited from different sources. However, when I went to the library, I noticed that there were not enough resources and I could not reach the sources I looked for" (S2)

\subsubsection{Friend Interaction}

Prospective teachers got help from their friends about taking materials from friends, asking for ideas, listening to the lessons from different classmates and preparing electric circuit with their friends before the application. Some candidates expressed that they had been faced with incomplete or incorrect guidance of their friends.

"S28 would construct circuit while he was teaching the lesson, and I would teach my lesson with the circuit prepared by him. S28 taught the lesson with 3 circuits. I needed 4 circuits. S29 and another friend of mine completed the last circuit during the time-off between two lessons." (S15)

\subsubsection{Emotions}

The most important concern prior to the application was about lesson activities. Candidates had concerns about the circuits that they would not work and the activities would not be appreciated enough. As a result of these concerns, they stated that they had frequently checked the circuits. In addition, there had been concerns about class participation, gains and time.

"I joined the class through a student exchange program this term. I had anxiety about how the class would react to my presentation and if they would participate in my activities." (S3)

\subsubsection{Gains}

Candidates expressed that; gains contained limited subjects, the activity and gains were incompatible, and they could not find suitable activities related to the gains. However, some prospective teachers stated that they had encountered easy gains and had not experienced any difficulties about them.

"I was relieved because I had an easy gain. I usually started preparing my lesson plan a couple of days earlier. Also, I got prepared easily because my gain was uncomplicated." (S10)

\subsubsection{Lesson Plans}

On this subject, some difficulties were experienced about formatting a plan and designing the educational process. Besides, it was stated that different techniques had been made use of in the assessment and evaluation process.

"When preparing a lesson plan for the evaluation phase, I am in favor of the use of alternative assessment techniques. When I read the plane construction activity, I liked it very much. I wanted to use it." (S10) 


\subsubsection{Technology and Instructional Technologies}

Pre- service teachers/ candidates had difficulties as they were unable to reach the information from the internet and had broken computers. In addition, there were some candidates taking the necessary photos by themselves. Regarding instructional technologies, they had difficulty in preparing worksheets or they had enjoyable time when preparing worksheets. There were also some candidates who drew transparencies by hand and stated them as an experience prior to the application.

"When I said I prepared everything for the presentation, the main board of my computer broke down and all the information was deleted. I found another computer and prepared everything again. After some time, the second computer broke down, too. I prepared my lesson plan again in another computer for the third time." (S14)

\subsubsection{Classroom Observations}

Before the application, another point expressed by the prospective teachers was examining other candidates and criticizing them, and paying attention not to make the same mistakes.

\subsection{Lesson Activity Experiences}

The themes related to prospective teachers' application process are; time, experiment materials, emotions, technology, instructional technology, groups, classroom management, presentation types, security measures and using the board (Appendix B).

\subsubsection{Emotions}

Some candidates; could not make an effective presentation depending on excitement, reflected out their anxiety, felt excited to be in front of a large group, and failed to cope with excitement. Candidates were happy for smooth sailing, and making an effective presentation in the classroom environment. Sometimes they experienced lack of motivation due to some problems during course presentation. However, some candidates indicated that they could not give a good representation depending on personal issues.

"I was very excited and excitement is a factor affecting me significantly in every moment of my life. Unfortunately, I cannot prevent it myself. Normally, I learned how to control my excitement sometimes, but I could not control my excitement in this presentation." (S20)

\subsubsection{Experiment Materials}

Material deficiencies were about lack of suitable materials meeting the purposes of the experiment, failure of circuits, materials not meeting the gains or not reaching the goal of the activity and not obtaining sufficient quantity of power supply and voltmeter materials. The activities of candidates bringing missing or incorrect materials were left half finished. Candidates not knowing how to use electronic equipment or using damaged or malfunctioning equipment faced difficulties about non-working equipment.

"There were $1.5 \mathrm{~V}$ bulbs in the classroom, but I needed $6 \mathrm{~V}$ bulbs. I had no chance but to use $1.5 \mathrm{~V}$ bulbs. Then, the power supply voltage was low and the bulb that should have lighted in some liquid solutions did not light up." (S7)

\subsubsection{Classroom Management}

Candidates were often faced with noise during course presentation and were forced to calm the students down. Some candidates thought their classmates showed their high level knowledge during the presentation. They also had difficulty in forming groups because of $U$ type order of seating. On the other hand, there were some candidates who thought they achieved classroom management and conducted the lesson with an effective tone of voice.

Student teachers doing effective management asked some questions to the class and they got answers from different students or groups during the application. Some candidates thought that participation was increased because the class liked the activity. However, reasons of not achieving effective participation can be listed as; not asking enough questions to the class, asking questions only to predetermined students, not including all members of crowded groups in group activities, and lack of student participation to the activities because of demonstrations.

\section{"My classmates tried their best to attend my lesson and help with my presentation" (S22)}

\subsubsection{Time}

Candidates who want to finish their presentation quickly either tried to finish their activities because of having an exam the same day or started to teach lesson accessing materials to all friends. Some of candidates using time unnecessarily listened to whole classmates when they asked a question, waited for too long although asked questions were solved, preferred long experiment processes, and had the students write notes frequently. On the other hand, candidates using time effectively and efficiently concentrated on their gains only and brought ready materials to the classroom considering the gains. 
"I understood that the most sensible thing I did that day was to set up the circuits before my presentation and bring them to the classroom. This is because if I had had my classmates prepare circuits, the class would have got very bored, much time would have been spent and a lot of noise would have been made" (S18)

\subsubsection{Technology and Instructional Technologies}

Prospective teachers used ready videos or videos prepared by themselves in the process of lecturing or elaboration process and they showed them to whole class with the projector. Some of the candidates showed the photos taken by themselves on a projector.

Candidates making use of teaching technologies preferred worksheets and transparencies. Prospective teachers using transparencies either showed the following steps in the exploration process or explained the matter making use of transparencies in the explanation process. Although worksheets were used by all candidates, there were some problems about using them effectively and efficiently, and some problems about the instructions and stages.

“... The video I would use in the explanation stage of my presentation did not open. My classmates tried to help me but they could not." (S13)

\subsubsection{Groups}

Created groups were crowded. Candidates often separated the class into three groups in their activities. This was because the experiment materials like ampere meters, voltmeters, and power supply could not be obtained sufficiently.

Some candidates helped all groups separately in group studies and some of them listened to the group spokesmen in their applications.

"Unfortunately, not having enough voltmeters have affected our presentation negatively. Because of very few materials, we have to form too crowded groups and this has affected our presentation badly."

\subsubsection{Presentation Types}

Prospective teachers preferring to visualize their lesson showed a picture and asked questions about it. Candidates preferring demonstration did some mistakes. For example, they prepared an activity out of the lesson plan, and they taught wrong information about the subject. Exemplification is one of the most preferred presentation types by prospective teachers, so it was preferred in the engagement process. Some candidates used analogy but one of them used wrong analogy. Candidates using explanation reminded prior knowledge or gave information about the subject. About all of them carried out an experiment in their teaching activity. However, they faced several challenges when conducting their experiments. Question and answer method was highly preferred by them. Yet, some candidates explained that they had not prepared effective questions or used them effectively in the class.

\subsubsection{Security Measures}

No precautions were taken for the hazards caused by warming electrical appliances, and this case caused hand burns of the candidates.

\subsubsection{Using the Board}

Some prospective teachers did necessary drawings by themselves when they used the board. Some of them asked for help from other candidates in the class to draw the necessary shapes for the lesson.

\section{Discussion and Conclusion}

Prospective teachers have faced technology-based problems before and during lesson activities. Using technology in the lesson process makes a significant contribution to the teachers to save time (Öğüt, Altun \& Koçer, 2003). Almost all candidates have made use of technology during lesson activities, although they have had difficulty in effective and efficient use of time. Using technology by the candidates in their lessons can be shown as a proof that they think technology is important for teaching the lessons effectively and efficiently. As a matter of fact, when literature has been reviewed, it is seen that prospective teachers believe in the positive effect of technology in the lessons (Şekerci et al., 2008; Usta \& Korkmaz, 2010). It can be concluded that prospective teachers have difficulty about time because their technological pedagogical content knowledge is not sufficiently developed. Similarly, it is known in the literature that prospective teachers are not sufficient in integrating technology into their lessons (Kaya, 2010; K1liç, 2011) and they need too much time to do this (Angeli, 2005). This can be shown as a proof of technology-based difficulties before and during application. Also, it is thought that candidates having knowledge about technology and looking to technology positively need to improve themselves about technological pedagogical content knowledge and they need to learn how to use technology effectively and efficiently in their lessons.

Prospective teachers have often expressed that they have had difficulties about groups. When the literature is reviewed, it points out that similar problems were experienced in different studies (Author, 2011; Eraslan, 2012). When the issues 
related with classroom management are taken into consideration, it emerges that candidates need to have more experience about carrying out group studies. It is known from previous studies that prospective teachers had some deficiencies about classroom management (Özay- Köse, 2010). For this reason, they sometimes preferred extracurricular activities, warned the class or asked some questions to the class. Similarly, it is declared that candidates apply some strategies like asking questions, drawing attention or warning to overcome the case (Çakmak, Kayabaşı \& Ercan, 2008). Experienced problems about classroom management have been related with inappropriate seating arrangement. Besides, it is observed that some difficulties have occurred in achieving classroom management in group studies. Effective classroom management can be seen as a concept proceeding with the professional development of teachers and getting mature with the development of new and different strategies. Hence, it is thought that candidates will develop different strategies as they gain experience in classroom management.

Prospective teachers have difficulty in controlling their feelings before and during application. When it is thought that the beliefs of prospective teachers affect their teaching activities (Yılmaz- Tüzün, 2008), the importance of prospective teachers' emotions becomes clear. It is known that feelings, beliefs and attitudes related with teaching cannot change easily (Ogan Bekiroğlu \& Akkoç, 2006), so it can be thought that experiencing similar problems is expected by candidates. In order to overcome this problem, it is suggested that studies on teaching practice can be carried out very often by prospective teachers.

Candidates mostly have difficulty about finding test equipment and using them properly. Similarly, it is declared in some studies that lack of test materials affects the presentations of prospective teachers (Karal- Eyüboğlu, 2011; Kocakülah \& Savaş, 2011; Ogan Bekiroğlu \& Akkoç, 2006). Student teachers usually use multi-meters, cables or lamps in the experiments related to electricity. It is known that these materials can be affected from variations of electric current and destroyed. It is thought that the problems experienced by candidates originate from not having enough practical knowledge about electrical applications. For this reason, it is suggested that candidates should make more applications about electricity and magnetism specifically.

It is determined that the most preferred presentation types by prospective teachers are question-and-answer, experiment and explanation. Constructivist theory was also preferred in applications by the candidates. Candidates have preferred experiment for exploration and elaboration, question and answer for engagement, exploration, explanation, elaboration and evaluation, explanation for the explanation process. One reason why these teaching techniques are preferred can be explained as there is native adaptation between these teaching techniques and 5E models phases. Similarly, Alev and Karal (2013) expressed that teachers preferred question and answer and experiment techniques for student centered approach and explanation for teacher centered approach. Another reason why explanation technique is preferred can be explained as candidates mostly receive education through teacher centered approach.

Consequently, candidates can sometimes develop negative attitudes toward teaching profession depending on their experiences (Özbek, Kahyaoğlu \& Özden, 2007). Sometimes, prospective teachers can find themselves sufficient before starting to profession (Özer \& Gelen 2008). In this context, it is known that teachers have difficulty about pedagogical content knowledge and technological pedagogical content knowledge in the early years in their profession and they are not expected to solve these problems by themselves (Gödek, 2006). For this reason, it can make us think that the difficulties faced by teachers are a part of their improvement in the development of pedagogical content knowledge. Thus, the point that the candidates consider themselves as deficient in some aspects may be an indication of challenges they face in terms of professional qualifications.

Pre-service teachers may encounter some problems in their first experiences. In order to overcome these problems, it could be wise to help them about their imperfect knowledge and positive behaviors by domain experts. In this way it could be contributed to their development. Pre- service teachers notice their deficiencies and they may overcome these problems sooner. It may be benefitted from reflective writings by teacher trainer in applications. Thus, they can examine pre-service teachers' development more closely.

In this study, pre- service teachers' only first experiences were examined. Hereafter carried studies, pre service science teachers first several experiences can be examined and more detailed conclusions can be reached about their development. Also, teachers' first year of professional development can be analysed in different studies and on this matter their developments can be searchable.

\section{References}

Adams, P. E., \& Krockover, G. H. (1997). Beginning science teacher cognition and its origins in the pre-service secondary science teacher program. Journal of Research in Science Teaching, 34(6), 633-653. doi: 10.1002/(SICI)10982736(199708)34:6<633::AID-TEA6>3.0.CO;2-O

Alev, N., \& Karal, I. S. (2013). Determining physics teachers' pedagogical content knowledge on electricity and 
magnetism topics. Mersin Üniversitesi Eğitim Fakültesi Dergisi, 9(2), 88-108.

Alev, N., \& Yiğit, N. (2006). Students' perceptions of assignments given in the courses as part of the application in the master's program without thesis. Türk Eğitim Bilimleri Dergisi, 4(3), 1-12.

Altunışık, R., Coşkun, R., Bayraktaroğlu, S., \& Yıldırım, E. (2005). Research methods in social sciences, (4th ed.). Sakarya, Turkey: Sakarya bookstore.

An, S., Kulm, G., \& Wu, Z. (2004). The pedagogical content knowledge of middle school mathematics teachers in China and the U.S. Journal of Mathematics Teacher Education, 7, 145-172. https://doi.org/10.1023/B:JMTE.0000021943.35739.1c

Angeli, C. (2005). Transforming a teacher education method course through technology: effects on pre-service teachers technology competency. Computer \& Education, 45, 383-398. https://doi.org/10.1016/j.compedu.2004.06.002

Author, (2011). (Unpublished doctoral dissertation). Karadeniz Technical University, Trabzon, Turkey.

Aydin, B. (2003). Training individuals in the process of forming knowledge society and teaching of mathematics. Pamukkale University Journal of Education, 2(14), 183-190.

Becit, G., Kurt, A. A., \& Kabakçı, I. (2009). Viewpoints of pre-service computer teachers on the advantageous of school practicum courses. Anadolu University Journal of Social Sciences, 9(1), 169-184.

Cengiz C., \& Karataş F. Ö. (2014). Developıng reflectıve thınkıng: effects of keepıng reflectıve journals with pre-service science teachers. Journal of Research in Education and Teaching, 3(4), 120-129.

Cole, A. L., \& Knowles, J. G. (1993). Shattered images: Understanding expectations and realities of field experiences. Teaching \& Teacher Education, 9(5-6), 57-71. https://doi.org/10.1016/0742-051x(93)90030-k

Çakmak, M., Kayabaşı, Y., \& Ercan, L. (2008). Teacher candidates' views about classroom management strategies. Hacettepe University Journal of Education, 35, 53-64.

Çepni, S. (2007). Introduction research and project studies (expanded 3th ed.). Trabzon: Celepler Matbaacilik.

Desouza, J. M., Boone, W. J., \& Yilmaz, O. (2004). A study of science teaching self-efficacy and outcome expectancy beliefs of teachers in India. Science Education, 88(6), 837-854. https://doi.org/10.1002/sce.20001

Driel, J. H. V., Jong, O. D., \& Verloop, N. (2002). The development of pre-service chemistry teachers' pedagogical content knowledge. Science Teacher Education, 86, 572-590. https://doi.org/10.1002/sce.10010

Eraslan, A. (2012). Prospective elementary mathematics teachers' thought processes on a model eliciting activity. Educational Sciences: Theory \& Practice, 12(4), 2953-2970.

Gödek, Y. (2006, May). Effective way of basic knowledge of prospective science teachers. Paper presented at III: International Teacher Training Symposium, Çanakkale, Turkey: 18 Mart University.

Haney, J. J., \& McArthur, J. (2002). Four case studies of prospective science teachers' beliefs concerning constructivist teaching practices. Science Education, 86, 783. https://doi.org/10.1002/sce.10038

Hart, L. C. (2002). Pre-service teachers' beliefs and practice after participating in and integrated content/methods course. School Science and Mathematics, 102(1), 4-14. https://doi.org/10.1002/sce.10038

Işık, A., Çiltaş, A., \& Baş, F. (2010). Teacher training and teaching profession. Atatürk University Journal of Graduate School of Social Sciences, 14(1), 53-62.

Karal, E. I. S. (2011). Development of physics teachers' pedagogical content knowledge (PCK) (Unpublished doctoral dissertation). KTÜ, Trabzon.

Kaya, O. (2009). The nature of relationships among the compenents of pedagogical content knowledge of pre-service science teachers: 'Ozone layer depletion' as an example. International Journal of Science Education, 31(7), 961-988. https://doi.org/10.1080/09500690801911326

Kaya, Z. (2010). Exploring pre-service science and technology teachers' technological pedagogical content knowledge (TPCK) involving the topic of photosynthesis and cellular respiration (Unpublished master's thesis). Firat University, Elazı̆

Kılıç, A. (2011). Exploring pre-service science and technology teachers' technological pedagogical content knowledge and classroom practices involving the topic of electric current (Unpublished master's thesis). Firat University, Elazı̆g.

Kiliç, H. (2009). The nature of pre-service teachers' pedagogical content knowledge [online], retrieved from http://www.cerme7.univ.rzeszow.pl/WG/17a/CERME7_WG17A_Kilic.pdf 
Kocakülah, A., \& Savaş, E. (2011). Prospective primary science teachers' views about the process of designing and practing experiments. Ondokuz Mayls University Journal of Faculty of Education, 30(1), 1-28. https://doi.org/10.7822/egt53

Merriam, S. B. (2009). Qualitative research: a guide to design and implementation (2nd ed.). USA: John Wiley \& Sons.

Miles, M. B., \& Huberman, A. M. (1994). Qualitative data analysis (2nd ed.). Sage: London.

Ng, W., Nicholas, H., \& Wiliams, A. (2010). School experience influences on pre-service teachers' evolving beliefs about effective teaching. Teaching and Teacher Education, 26 (2), 278-289.

https://doi.org/10.1016/j.tate.2009.03.010

Özay-Köse, E. (2010). Pre- service Teachers' ideas about classroom management. Çukurova University Faculty of Education Journal, 39, 20-27.

Özer, B., \& Gelen, İ. (2008). Having general adequacy of teaching profession evaluation of the views of teacher candidates and teachers about their level. Mustafa Kemal University Journal of Social Science Institute, 5(9), 39-55.

Ogan-Bekiroğlu, F., \& Akkoç, H. (2009). Pre-service teachers' instructional beliefs and examination of consistency between beliefs and practices. International Journal of Science and Mathematics Education, 6(7), 1173-1199. https://doi.org/10.1007/s10763-009-9157-z

Öğüt, H., Altun, A. A., \& Koçer, H. E. (2003). E-learning with computer aided, access to internet interactive education Cd. Turkish Online Journal of Educational Technology, 2(4), 67-75.

Özbek, R., Kahyaoğlu, M., \& Özgen, N. (2007). Evaluation of candidate teachers' opinions on teaching profession. Afyon Kocatepe University Journal of Social Sciences, 9(2), 221-233.

Prosser, M., \& Trigwell, K. (1997). Relations between perceptions of the teaching environment and approaches to teaching. British Journal of Educational Psychology, 67, 25-35. https://doi.org/10.1111/j.2044-8279.1997.tb01224.x

Raths, J. (2001). Teachers' beliefs and teaching beliefs. Early Childhood Research and Practice, 3(1). Retrieved from http://ecrp.uiuc.edu/v3n1/raths.html

Robson, C. (1993). Real word research, a resource for social scientists and practioner-researchers. Oxford, UK \& Cambridge, USA: Black Well Publishers.

Roskos, K., \& Walker, B. J. (1994). Learning to teach problem readers: instructional influences on pre-service teachers' practical knowledge. Journal of Teacher Education, 45(4), 279-288. https://doi.org/10.1177/0022487194045004006

Shulman, L. S. (1986). Those who understand: knowledge growth in teaching. Educational Researcher, 15(2), 4-14. https://doi.org/10.3102/0013189X015002004

Shulman, L. S. (1987). Knowledge and Teaching: foundation of the new reform. Harvard Educational Review, 57(1), 1-21. https://doi.org/10.17763/haer.57.1.j463w79r56455411

Sperandeo-Mineo, R. M., Fazio, C., \& Tarantino, G. (2005). Pedagogical content knowledge development and pre-service physics teacher education: a case study. Research in Science Education, 36(3), 235-268. https://doi.org/10.1007/s11165-005-9004-3

Şekerci, A. R., Kurban, B, Çimen, N., Kızıltaş, E., Turan, S., ... Göktaş, Y. (2008, May). Circumstance of instructional technology in education faculty: student ideas. Paper presented at the 8th International Educational Technology Conference, Eskisehir: Anadolu University.

Tosun, T. (2000). The beliefs of pre-service elementary teachers toward science and science teaching. School Science and Mathematics, 100, 374-379. https://doi.org/10.1111/j.1949-8594.2000.tb18179.x

Usta, E., \& Korkmaz, Ö. (2010). Pre-service teachers' computer competencies, perception of technology use and attitudes toward teaching career. International Journal of Human Sciences, 7(1), 1335-1349.

Wilkins, J., \& Brand, B. (2004). Change in pre-service teachers' beliefs: An evaluation of a mathematics methods course. School Science and Mathematics, 104, 226-232. https://doi.org/10.1111/j.1949-8594.2004.tb18245.x

Y1lmaz-Tüzün, O. (2008). Pre-service elementary teachers' beliefs about science teaching. Journal Science Teacher Education, 19, 183-204. https://doi.org/10.1007/s10972-007-9084-1 
Yin, R. K. (2009). Case study research: design and methods (4th edt.). USA: SAGE Inc.

Yin, R. K. (2011). Qualitative research from start to finish, NY: the Guilford Press.

Yüksek, Ö. K. (2007). Higher Education Council of Turkey. (2007). Teacher training and education faculties (19822007) (evaluation of training of teachers in university). Ankara, Turkey: Higher Education Council of Turkey Press, 2007-5.

\section{Appendix}

Appendix A. Experiences of candidates before teaching activities

\begin{tabular}{|c|c|c|}
\hline Theme & Activity & Student code \\
\hline \multirow[t]{3}{*}{ Time } & The last day studying & $\mathrm{S} 4, \mathrm{~S} 7, \mathrm{~S} 10, \mathrm{~S} 15, \mathrm{~S} 17, \mathrm{~S} 22, \mathrm{~S} 24, \mathrm{~S} 28$ \\
\hline & Intensity of lesson & $\mathrm{S} 1, \mathrm{~S} 12, \mathrm{~S} 18, \mathrm{~S} 27$ \\
\hline & Early preparation & S25 \\
\hline \multirow[t]{4}{*}{ Experiment materials } & Coming with lacking or incorrect materials & $\mathrm{S} 8, \mathrm{~S} 28$ \\
\hline & Not finding necessary materials & $\begin{array}{l}\text { S2, S3, S5, S6, S7, S10, S13, S14, S16, S17, } \\
\text { S21, S22, S23, S24 }\end{array}$ \\
\hline & Defective materials & S9, S13 \\
\hline & No problem & S8 \\
\hline Lesson and & Deficiency of supplementary materials & $\mathrm{S} 2$ \\
\hline \multirow[t]{2}{*}{ supplementary books } & Not accessing lesson books & S13, S19 \\
\hline & Insufficient guidance of lesson book & S20 \\
\hline \multirow[t]{5}{*}{ Friend interaction } & Material supporting & S9, S13, S15, S16, S21, S26 \\
\hline & Activity supporting & S15 \\
\hline & Idea supporting & $\mathrm{S} 1, \mathrm{~S} 11, \mathrm{~S} 16, \mathrm{~S} 22$ \\
\hline & Receiving incomplete or incorrect idea & $\mathrm{S} 8, \mathrm{~S} 20, \mathrm{~S} 27$ \\
\hline & Preparation circuit & $\mathrm{S} 12$ \\
\hline \multirow[t]{4}{*}{ Emotions } & Concerns regarding with activities & $\mathrm{S} 1, \mathrm{~S} 18, \mathrm{~S} 21, \mathrm{~S} 23$ \\
\hline & Concerns about class participation & S3 \\
\hline & Concerns about time & S2 \\
\hline & Concerns about gains & S21 \\
\hline \multirow[t]{4}{*}{ Gains } & Gains include limited activities & S9, S28 \\
\hline & Inability to find suitable activities & S6, S19, S20 \\
\hline & Easy gains & $\mathrm{S} 10, \mathrm{~S} 11$ \\
\hline & Inconnection between gain and activity & S5 \\
\hline \multirow[t]{3}{*}{ Lesson plans } & Preparing reports & S6, S20, S24 \\
\hline & Assessment techniques & $\mathrm{S} 10$ \\
\hline & Designing stages & $\mathrm{S} 2, \mathrm{~S} 3, \mathrm{~S} 20, \mathrm{~S} 26$ \\
\hline Technology and & Benefiting from the Internet & $\mathrm{S} 3, \mathrm{~S} 19, \mathrm{~S} 20, \mathrm{~S} 24$ \\
\hline \multirow[t]{5}{*}{ instructional technologies } & Difficulties in worksheets & S10, S19 \\
\hline & Liking to prepare worksheets & $\mathrm{S} 18, \mathrm{~S} 24$ \\
\hline & Scratching transparencies with hand & S24 \\
\hline & Camera & $\mathrm{S} 24$ \\
\hline & Computer problems & S14 \\
\hline
\end{tabular}

Note. $S 1$, S2, S3,... obtained from reflective writings 
Appendix B. Teaching experiences process of candidates

\begin{tabular}{|c|c|c|}
\hline Theme & Activity & Student code \\
\hline \multirow[t]{4}{*}{ Emotions } & Excitement & S4, S14, S18, S19, S20, S22, S23, S26, S27, S15, S18 \\
\hline & Happiness & $\mathrm{S} 21, \mathrm{~S} 24, \mathrm{~S} 28$ \\
\hline & Personal problems & S19 \\
\hline & Lack of motivation & $\mathrm{S} 4, \mathrm{~S} 20$ \\
\hline \multirow{3}{*}{$\begin{array}{l}\text { Experiment } \\
\text { materials }\end{array}$} & Lack of materials & S6, S7, S10, S19, S22, S10, S24 \\
\hline & Wrong materials & S8, S14, S4, S6, S7, S9, S24 \\
\hline & Failure of materials & S9, S19, S14, S29 \\
\hline \multirow{6}{*}{$\begin{array}{l}\text { Classroom } \\
\text { management }\end{array}$} & Seating systems & $\mathrm{S} 3, \mathrm{~S} 19, \mathrm{~S} 29$ \\
\hline & Classroom noise & $\begin{array}{l}\text { S1, S2, S3, S14, S18, S24, S25, S29, S2, S3, S7, S12, S18, S19, } \\
S 24, S 27, S 29\end{array}$ \\
\hline & Class level & S9, S19, S25 \\
\hline & Effective class domination & S25 \\
\hline & Non-active class participation & $\mathrm{S} 13, \mathrm{~S} 20, S 3, S 11, S 17, S 24$ \\
\hline & Active class participation & $\begin{array}{l}\text { S11, S22, S26, S1, S9, S14, S16, S18, S19, S20, S22, S23, S24, } \\
S 25, S 26\end{array}$ \\
\hline \multirow[t]{3}{*}{ Time } & Wanting early termination & $\mathrm{S} 1, \mathrm{~S} 8, \mathrm{~S} 22$ \\
\hline & Using time effectively & $\mathrm{S} 18, \mathrm{~S} 22, S 7, S 12, S 18, S 25$ \\
\hline & Waste of time & $S 2, S 9, S 12, S 15, S 21, S 23$ \\
\hline \multirow{4}{*}{$\begin{array}{ll}\text { Technology and } \\
\text { instructional } \\
\text { technologies }\end{array}$} & Video & S13, S5, S13, S19 \\
\hline & Worksheets & $S 5, S 9, S 21$ \\
\hline & Transparency & $S 2, S 24$ \\
\hline & Photo & $S 24$ \\
\hline \multirow[t]{5}{*}{ Groups } & Creating crowded groups & $\mathrm{S} 2, \mathrm{~S} 3, \mathrm{~S} 10, \mathrm{~S} 24, \underline{\mathrm{S} 28}$ \\
\hline & Group studying & $S 2, S 22, S 29$ \\
\hline & Helping the groups & $S 27$ \\
\hline & Security measures & $S 8, \underline{\mathrm{S} 3}$ \\
\hline & Blackboard usage & $S 2,520$ \\
\hline \multirow[t]{7}{*}{ Presentation types } & Visualization & $S 24$ \\
\hline & Demonstration & S19, $\underline{\mathrm{S} 22}$ \\
\hline & Sampling & $\mathrm{S} 22, \overline{S 4}, \mathbf{S} 22, \underline{\mathrm{S} 3, \mathrm{~S} 7, \mathrm{~S} 11, \mathrm{~S} 19}$ \\
\hline & Simulation & $\underline{\mathrm{S} 21}$ \\
\hline & Explanation & $\begin{array}{l}\text { S4, S27, S1, S4, S5, S11, S15, S23, S25, S26, S27, S4, S10, } \\
\text { S12, S15, S22, S23, S27, S28, S29 }\end{array}$ \\
\hline & Experiment & $\begin{array}{l}\text { S19, S3, S4, S6, S7, S8, S16, S17, S18, S19, S22, S23, S26, S28, } \\
\text { S29, S4, S5, S6, S8, S9, S10, S13, S14, S20, S23, S27, S28, S29 }\end{array}$ \\
\hline & Question and answer & $\begin{array}{l}\text { S14, S3, S4, S10, S12, S17, S18, S22, S26, S27, S28, S24, S1, } \\
\text { S3, S7, S }, \text { S10, S11, S12, S13, S15, S16, S18, S19, S22, S23, } \\
\text { S24, S25, S26, S28 }\end{array}$ \\
\hline
\end{tabular}

Note: S1, S2, S3, ... obtained from reflective writings

$S 1, S 2, S 3, \ldots$ obtained from lesson observations

$\mathrm{S} 1, \mathrm{~S} 2, \mathrm{~S} 3, \ldots$ obtained from lesson plans

\section{Copyrights}

Copyright for this article is retained by the author(s), with first publication rights granted to the journal.

This is an open-access article distributed under the terms and conditions of the Creative Commons Attribution license which permits unrestricted use, distribution, and reproduction in any medium, provided the original work is properly cited. 